The

\title{
Do the European Union's bilateral investment treaties matter? The way forward after Lisbon
}

\section{CEPS Working Document No. 333/ J uly 2010}

\author{
Selen Sarisoy Guerin
}

\begin{abstract}
Several policy-relevant issues regarding the EU's bilateral investment treaties (BITS) are addressed in this paper. First and foremost, we explore the question of whether EU's BITs have a significantly positive impact on outflows or not. Second, we ask the question which member states and which BIT partners have had a significant experience after the implementation of the BIT. In our sample we find that both OECD BITs and EU BI Ts have a statistically significant and positive impact on FDI outflows. This result is robust to the inclusion of variables such as privatisation proceeds that control for the level of economic reform, the level of trade linkages, the level of democratic freedom and a measure of risk of expropriation among other standard controls. We control for endogeneity in our estimations by using the fixed-effects estimator as our preferred estimator on a large panel dataset. We also test the strict exogeneity of our results by using a method suggested by Baier and Bergstrand (2007) and we find no feedback effect in our sample.
\end{abstract}

CEPS Working Documents are intended to give an indication of work being conducted within CEPS research programmes and to stimulate reactions from other experts in the field. Unless otherwise indicated, the views expressed are attributable only to the author in a personal capacity and not to any institution with which she is associated. 


\section{Contents}

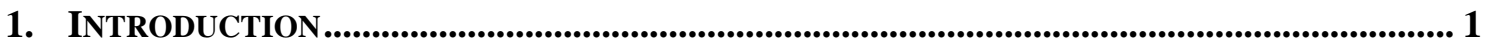

2. FOREIGN DIRECT INVESTMENT AND BILATERAL INVESTMENT TREATIES OF THE EU ... 2

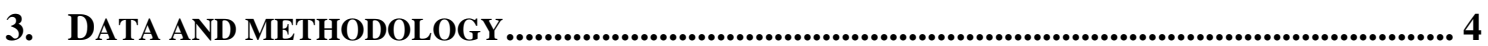

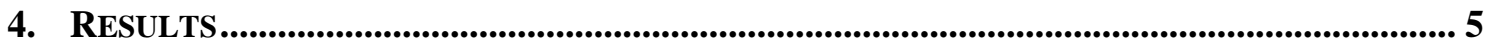

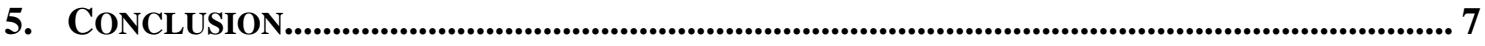

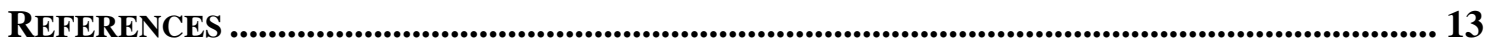




\title{
DO THE EUROPEAN UNION'S BILATERAL INVESTMENT TREATIES MATTER? THE WAY FORWARD AFTER LISBON
}

\author{
CEPS WORKING DOCUMENT NO. 333/JULY 2010 \\ SELEN SARISOY GUERIN ${ }^{*}$
}

\section{Introduction}

The Lisbon Treaty entered into force on 1 December 2009 and has brought about at least one significant change in the area of EU's common commercial policy. The Treaty on the Functioning of the European Union now places foreign direct investment as an area of exclusive EU competence. This means that the EU is now the sole negotiator of international investment treaties and that member states can no longer negotiate international agreements on foreign direct investment with third countries. ${ }^{1}$ Although the issue of how the transfer of competences in this area from member states to the EU should be handled is better left to EC lawyers, there are several important questions that economists should address to contribute to future investment policy in the EU.

The aim of this paper is to address several questions that are relevant to the EU's future investment policy. The EU Commission is in the process of drafting a proposal on how to grandfather all 1,557 existing bilateral investment treaties of the 27 member states to integrate member state Bilateral Investment Treaties (BITs) into EU law. Hence, the first question we address in this paper is to empirically test whether the existing member state BITs have the desired positive impact on foreign direct investment (FDI) outflows to the host developing countries. By default BITs are intended to promote and protect investment in the contracting country by the counterparty investor. Typically, the BITs define the type of investment and investor that is covered. In addition to this, BITs are intended to protect the investor against arbitrary expropriation by the host country government without compensation and offer an investor-to-state dispute settlement mechanism. As such, BITs are intended to reduce risk to investment.

The empirical literature on the impact of bilateral investment treaties on FDI flows is ambiguous. While several studies indicate that the relationship between BITs and FDI is positive and statistically significant (e.g. Busse et al, 2008; Egger and Pfafferamayr, 2004; Neumayer and Spess, 2005; Salacuse and Sullivan 2004), several others either find a negative or no statistically significant relationship (e.g. Hallward-Driemeier, 2003 and Tobin and RoseAckerman, 2004). Recent literature has recognised that several of these studies fail to find a significant relationship between BITs and FDI as they do not account for endogeneity. Indeed, it is difficult to assess the impact of BITs on FDI while the selection of the BIT partner is endogeneously determined. In addition to the reverse causality, the potential endogeneity in BIT/FDI literature is further exacerbated by omitted variables bias.

We use large panel data of bilateral FDI inflows to 25 middle-income developing countries from 14 OECD member countries over the period 1992-2004 to examine the impact of member state

\footnotetext{
* Senior Researcher, Institute of European Studies, VUB.

${ }^{1}$ The member states may still be empowered to negotiate their individual bilateral investment treaties (BITs).
} 


\section{2 | SELEN SARISOY GUERIN}

BITs on FDI. This period captures both the surge in global FDI flows and the number of BITs signed and implemented. As International Centre for Settlement of Investment Disputes (ICSID) statistics indicate, the number of BITs in the world increased from 636 in 1992 to 2,216 in 2004. Analogous to literature on the impact of free trade agreements on trade, we use BIT treatment effect à la Baier and Bergstrand (2007). In order to address concerns over potential endogeneity in our model, we use a modified gravity-type model and estimate the relationship between BITs and FDI by a fixed-effects model controlling for both country-pair fixed effects and time effects. Models estimated with country-pair fixed-effects are shown to effectively eliminate the selection bias (e.g. Razin et al., 2003; Helpman et al., 2005). We find a positive and statistically significant impact of the existing BITs on member states' FDI in the sample developing countries. We test the robustness of our results against the omitted variable bias, strict exogeneity and also sensitivity against different estimation techniques. The positive impact of BITs on EU FDI in the developing countries is robust when the level of economic and political reform in the host country is controlled for by introducing the level of privatisation proceeds in the host country, an index of risk of expropriation, the level of democratic development and the level of trade linkages. The economic impact of BITs on member states' FDI outflows is stronger in estimations using both random effects and pooled OLS models. Following Baier and Bergstrand (2007), we control for strict exogeneity and find no feedback effect from FDI outflows to BITs.

We also address two other policy relevant questions. In its Roadmap (2010), the EC Commission raises the question of what a EU BIT should look like. To address this issue, we first ask whether some member states' BITs could be identified as having a significantly more positive effect on FDI than others. The impact of the BIT can work through two channels: by effectively reducing risk to investment and by increasing market access through FDI liberalisation. ${ }^{2}$ Our results indicate that the entry into force of BITs of Austria and France had a statistically significant positive effect on their FDI outflows. There is also evidence that BITs of Austria exert a positive influence on FDI outflows through protection of investment and reducing risk, whereas in France BITs also have provided significant market access.

Second, we address the question of with which countries the EU should negotiate its new investment treaties. As the Roadmap indicates, when the transition period of grandfathering of existing BITs comes to an end, the EU is going to choose a number of third countries to negotiate with. We argue that the priority should be given to those where the existing BITs have had a positive impact already. Among EU's BIT partners only Philippines, Romania and South Africa have positively benefited from signing BITs with the EU.

The next section discusses both patterns of FDI outflows of the EU and its selection of BIT partners. Section 3 introduces description of data and methodology and section 4 follows with results. Section 5 concludes.

\section{Foreign Direct Investment and Bilateral Investment Treaties of the EU}

In this section we examine the outward FDI performance of the EU and present some qualitative analysis of its bilateral investment treaties. The EU27 is the number one source of FDI flows globally. The total FDI outflows of the EU27 peaked at $€ 1.2$ trillion in 2007 (more than four times FDI outflows invested by the US) with FDI outward stocks reaching $€ 8.2$ trillion in the same year. As FDI is also home-biased like trade, the majority of EU27 FDI outflows are destined to other member states. Intra-EU27 FDI outflows reached $€ 707$ billion, leaving $€ 530$

\footnotetext{
2 Contrary to the BITs signed by the US and recently by Canada, EU BITs rarely provide FDI liberalisation through offering MFN treatment during the pre-establishment period of the investment.
} 
billion for extra-EU27 outflows in $2007 .^{3}$ In terms of most favoured extra-EU destinations, North America is by far the largest recipient of EU FDI outflows with a peak in 2007 at $€ 199$ billion. In other regions of the world, the EU27 invested €25.2 billion in Latin America, €17.9 billion in Africa, $€ 53.9$ billion in Asia.

The first question one would ask is whether countries that have signed bilateral investment treaties with the EU are receiving significantly larger amounts of FDI compared to non-BIT partners. As a start, we can see in Table 1 that the EU27 have signed 1,557 BITs to date compared to Japan and the US, which have signed 11 and 48 BITs only respectively (ICSID, 2010). Among the member states, with 147 BITs signed, Germany is by far the most active proponent of BITs. Germany is also the member state with the oldest BIT in the world: Germany negotiated and signed its first BITs with Pakistan and the Dominican Republic in 1959. Germany negotiated several BITs with many countries in Africa and Asia in the 1960s as well. Nevertheless, among the member states, the UK has accumulated the largest extra-EU FDI outward stocks, followed by France and then Germany (Table 1). ${ }^{4}$ One can observe that the EU member states that have the highest number of BITs also have the largest stocks of FDI invested abroad. This may suggest that indeed the promotion and protection offered by BITs may be encouraging FDI outflows.

There are several other factors that play a role in the selection of a host location for FDI. The empirical literature indicates that country size and income play a positive role whereas distance deters investment, much the same as for trade. Factors that facilitate the flow of information, such as sharing a common language, common law origin, having signed a regional trade agreement, and indeed trade flows all encourage FDI. Hence the selection of the BIT partner may not be exogenous. For example, among all the developing countries of the world, only a subset of them receive the majority of FDI. Indeed the so-called emerging market economies have been highly successful in attracting FDI. As can be seen in Table 2, there are diverse patterns in terms of the region that each member state prefers for its BIT partners. For example, Germany has signed BITs with 47 countries out of 53 in Africa, 26 out of 41 in Asia and 22 out of 32 in Latin America. On the other hand, France has signed BITs with most countries in Latin America (20 out of 32) and least with countries in Africa (21 out of Africa). Overall, the coverage ratio of BITs is higher for Asia than for Latin America and lowest for Africa. Detailed examination of data does not always suggest that the date of signature of a BIT has an immediate impact on FDI flows. For example, for several African countries, the flows have always been small both before and after the BIT. In contrast, for emerging market economies like Brazil, FDI flows have always been large.

Table 3 below shows in the first column the number of member states that have signed a BIT with an emerging market economy. These countries are among the few in each region to receive the majority of FDI. Indeed with the exception of Brazil and Colombia, the majority of EU15 member states and some of the new member states have signed BITs with all the emerging market economies. ${ }^{5}$ Even though Brazil has not ratified any of its bilateral investment treaties, the EU has FDI outward stocks of $€ 112$ billion in Brazil. Contrary to what one might expect, FDI stocks in China are limited and less than FDI stocks in Turkey. Even though 24 member

\footnotetext{
${ }^{3}$ In detail, extra-EU15 outflows were $€ 580$ billion in 2007 indicating that the 12 new member states actually disinvested during 2007.

${ }^{4}$ The same holds true even when one examines the global (including other EU member states) FDI outward stocks of Germany and the UK.

${ }^{5}$ The case of Brazil stands out from the others as nine member states have signed BITs with Brazil but they were not implemented. This was due to political and constitutional concerns by Brazil.
} 
states have signed BITs with China, with the exception of Austria-China and BelgiumLuxembourg-China BIT, the majority were signed in the last decade.

In Table 3, column 3 we present FDI investment income flows from each emerging market economy to the EU27. One important criterion for the choice of investment location is the return to investment given risk. Anecdotal evidence indicates that investors first choose a region and then a country in that region to invest. This may explain why a few countries in each region receive the majority FDI inflows from the world. If the decision to negotiate a BIT is endogenous, then we would expect to see large flows prior to signature of the BIT. High return may also encourage investment that in return may increase the probability of selection into a BIT. Among the emerging market economies, Chile presents the highest return to EU FDI, by $14 \%$, followed by Malaysia, Indonesia and Korea. All of these countries have signed BITs with the EU15 and some of the new member states. Turkey, which has signed 21 BITs with the EU27, so far has a low rate of return; 5\% like Morocco. Return to FDI has also been modest in China, with 7\% return to EU investment where there are 24 BITs signed.

In this section, we present some patterns in FDI outflows and a selection of BIT partners of the EU. The EU is the world's largest FDI investor and is the first ever BIT negotiator. Member states rely on BITs to a larger extent than the US and Japan. The qualitative analysis in this section shows that each member state has negotiated several BITs with a different set of countries in each region. However, there is a tendency to negotiate BITs more with Asian and Latin American countries than with African countries. Finally, EU member states have negotiated BITs with all emerging market economies that have been successful in attracting FDI. There is also a positive correlation between the total number of BITs signed and FDI outflows.

\section{Data and methodology}

In this section we describe the data and methodology used in order to test the differential impact of EU's BITs on FDI outflows. To this end we have constructed a large dataset of bilateral FDI flows using OECD's International Investment Statistics database. The panel dataset includes 14 OECD countries as reporters and 25 middle-income emerging market economies as partners over the period 1992-2004. This dataset covers over 90\% of EU's FDI outflows.

We model the EU's FDI outflows using a modified gravity model. Gravity models have been extensively used in modelling bilateral trade flows and, recently, FDI flows, and have been empirically highly successful with recent theoretical background as well. We argue that among several panel estimation techniques, using the fixed-effects model is theoretically the most suitable. As Baier and Bergstrand (2007) show, fixed-effects models on panel data including bilateral (country-pair) fixed-effects and country-and-time (it, jt) dummies are superior to other estimations methodologies such as pooled OLS, or random-effects models. One of the most important advantages of using a fixed-effects model on our panel data is that we will be able to control for unobserved endogeneity, which is raised as a concern in literature. After all, it is widely accepted that investment policy cannot be exogeneous to investment volumes. Solving the problem of endogeneity is extremely cumbersome using methods such as instrumental variable (IV) techniques simply because it is difficult to find good proxies of a investment policy, i.e. an BIT.

Unlike other estimation techniques, for example with OLS on cross-section data that produce biased estimates, or random-effects models that assume no correlation between unobservables $\left(\mathrm{a}_{\mathrm{ij}}\right)$ and the BIT variable, the fixed-effects estimator is an unbiased and consistent estimator of the treatment effect of a BIT. The downside of the fixed-effects estimator is that one cannot include time-invariant variables in the model as fixed-effects takes into account the within 
variation in the data and hence wipes out any time-invariant variables in the model. In other words, all time-invariant variables that are part of the standard gravity models such as bilateral distance, common language, adjacency, etc. will be subsumed by the country-pair fixed-effect $a_{\mathrm{ij}}$. One final concern regarding the choice of a fixed-effects estimator is that due to the particular shape of our dataset, where n (number of country-pairs $=350$ ) are large and the timeseries dimension of our dataset is short $\mathrm{t}=12$, the fixed-effect estimator suffers from the 'incidental parameter' problem (Baltagi, 2001) and hence produces inconsistent estimates of dummy variables. In order to adjust for that, we will present results from within effect estimator.

In order to estimate the treatment effect of EU's BITs on EU's FDI outflows with its investment partners, we estimate the following equation:

$$
\begin{aligned}
\operatorname{Ln}(\mathrm{FDI})_{\mathrm{ijt}}=\alpha_{\mathrm{ij}}+ & \ln (\mathrm{GDP})_{\mathrm{it}}+\ln (\mathrm{GDP})_{\mathrm{jt}}+\ln (\text { Income })_{\mathrm{it}}++\ln (\text { Income })_{\mathrm{jt}}+\mathrm{BIT}_{\mathrm{ijt}} \\
& +\mathrm{X}_{\mathrm{jt}}+\mathrm{t}_{\mathrm{ij}}+\mathrm{e}_{\mathrm{ijt}}
\end{aligned}
$$

The dependent variable, $\ln (F D I)_{i j t}$ is the natural $\log (\ln )$ of 14 OECD member country FDI outflows in constant \$US dollars to their 25 investment partners. In order to control for the impact of the size of the OECD country and the emerging market economies, we introduce real GDP of both the reporter (i) and the partner (j) at time $t$ in natural log. We also introduce real GDP per capita of both the investor and host as proxies of income. We would expect a positive relationship between the GDP per capita and FDI volumes as the two countries converge in levels of income. In an analogy to the Linder hypothesis, we expect that the more similar the demand structure of two countries are, as proxied by GDP per capitas, the more intense the potential flows between them will be. All GDP and GDP per capita variables are from the IMF's World Economic Outlook April 2010 database. Finally, we use a BIT dummy variable that takes on the value 1 when the reporting OECD country signed a BIT with the partner country and zero otherwise. The data on the dates of BITs are from the database of the International Centre for Settlement of Investment Disputes. ${ }^{6}$

\section{Results}

In this section we present results on the differential impact of bilateral investment treaties on FDI outflows. In Table 4, we test first the impact of OECD BITs in general in our sample. As the ICSID statistics indicate our sample period, 1992-2004, covers a period of greater activity where the number of BITs in the world increased from 636 in 1992 to 2,216 in 2004. In Table 4 we regress FDI outflows from OECD countries to emerging market economies on standard gravity variables, GDP, income, distance a set of control variables such as bilateral trade flows, privation proceeds in \$US, and a dummy for colony. We control for trade flows as countries that trade more also tend to invest more. In other words, trade can act as a channel for information, increasing familiarity and hence reducing transaction costs in a host country. We use privatisation proceeds in \$US millions from the World Bank's Privatization Database to control for the level of economic reform the emerging economies went through. We also use a dummy for colony to identify whether the host country has ever been colonised by the source country.

Both for theoretical and econometric reasons, we focus on the results of the fixed-effects estimator in column 1 but we present random-effects and pooled OLS results in column 2 and 3 as well. The results in column 1 indicates that BITs have a statistically significant and positive impact on the FDI outflows from 14 OECD source countries to their BIT partner. The coefficient of BIT indicates that when the BIT is implemented the source country FDI increases

\footnotetext{
${ }^{6}$ For the date of BIT, we use the date of implementation and not the date of signature. Later we will also use the date of signature to measure the signalling effect of BITs.
} 
by $1.32 \%{ }^{7}$ Other variables that are statistically significant have the expected positive sign with the exception of GDP per capita of the host country. In columns 2 and 3 we can control for time-invariant variables such as distance and colony. Controlling for distance and colonial history, BITs have a robust positive impact on FDI in both random-effects and pooled OLS models.

In Table 5 we test the robustness of EU's BITs using the same specification as in Table 4. Both in fixed-effect and random effect models EU BITs have a statistically significant and positive impact on FDI, indicating an estimated 1.32\% increase in FDI through time. In Table 6, we test the robustness of EU BITs by introducing several potential explanatory variables to reduce the probability of endogeneity due to omitted variable bias. In this table and the ones that follow we present results only from the fixed-effects estimator. We add the POLITY2 variable from the POLITY IV project of University of Maryland to measure the level of democracy in the host country. This index ranges from -10 to 10 , increasing as the host countries' political freedom improves. We expect that as a country becomes more democratic, it should receive more FDI as political reform and economic reform are shown to be positively correlated (see, for example, Persson, 2005).

In this paper we will argue that the effect of the BIT may work through two channels: first, the BIT may encourage FDI by reducing the risk of expropriation; second by providing better market access. In general, EU BITs provide post-establishment rights granting the investor equal rights as the domestic investor. However, there are some BITs that also provide FDI liberalisation through granting MFN rights by including pre-establishment clauses. In an attempt to discriminate between the two channels mentioned above, we introduce a political risk index referred to the host economy and ranging from 0 (highest risk) to 25 (lowest risk). This index is computed by Eschenbach et al. (2004) based on the Euromoney political risk index, and provides a (subjective) assessment of the risk of non-payment or non-servicing of payment for goods or services, loans, trade-related finance and dividends, as well as of the risk of nonrepatriation of capital. This index is a proxy for the risk of expropriation, and helps us control for the effect of political risk on FDI inflows. In column 1, Table 3, the EU BIT dummy is robust to the inclusion of the POLITY dummy. In column 2 we control for RISK in the host country as well and the economic impact of the EU BIT increases slightly and this variable has a positive impact as expected. This may suggest that BITs do not only provide investor protection to EU investors but also increase market access.

Table 7 presents results from BITs of different member states. The motivation here is to see whether there is a pattern in which certain member states' BITs deliver better results. Indeed, we can see that the coefficient of BITs is positive for several member states but only statistically significant for Austria and France. There is evidence in our sample that Portugal has been negatively affected by its BITs. However, when we control for the risk of expropriation, only France remains as a beneficiary of its BITs. This may indicate that Austria might be choosing its BITs partners among the riskier emerging economies to protect from expropriation. France on the other hand, might be achieving market access as well.

In Table 8 we explore the differential impact of the BIT due to the selection of the BIT partner. In other words, we ask the question: which host countries have benefited from the EU's BITs? Our results indicate that only the Philippines, Romania and Slovenia have increased FDI inflows after the implementation of the EU BITs, whereas Hungary has received less FDI. Finally, we

\footnotetext{
${ }^{7} \operatorname{Exp}^{(0.28)}=1.32$
} 
check the robustness of our results and test for endogeneity by introducing a dummy on BITs for $\mathrm{t}+1$, following Baier and Bergstand (2007). We find no feedback-effect in our sample. ${ }^{8}$

\section{Conclusion}

Several policy relevant issues regarding EU's bilateral investment treaties have been addressed in this paper. Since the Lisbon Treaty, the right to negotiate investment treaties has been transferred to the Commission from the member states. As the world's largest source of FDI outflows, the EU27 has signed 1557 BITs, compared to the US, which has only 48 and Japan 11. As the existing BITs will be grandfathered, several questions remain unanswered. First and foremost, we explored the question whether EU's BITs have a significantly positive impact on outflows or not. Second, we asked the question which member states and which BIT partners have had a significant experience after the implementation of the BIT.

In our sample, we found that both OECD BITs and EU BITs have a statistically significant and positive impact on FDI outflows. This result is robust to the inclusion of variables such as privatisation proceeds that control for the level of economic reform, the level of trade linkages, the level of democratic freedom and a measure of risk of expropriation among other standard controls. Our results are also robust in terms of the selection of estimator. We controlled for endogeneity in our estimations by using the fixed-effects estimator as the preferred estimator on a large panel dataset. As most of the time the endogeneity is due to uncontrolled unobserved heterogeneity, using fixed-effects on panel data is an efficient method to deal with endogeneity. We also tested the strict exogeneity of our results by using a method suggested by Baier and Bergstrand (2007) and we found no feedback effect in our sample.

Our results have a number of important policy implications. First, it is important to ensure investor security throughout the transition period. As our results indicate, BITs have been an effective tool so far. Next, it is important to decide the shape and contents of an EU BIT. This could be based on best practice. Here, our results are suggestive as we do not consider the details of the BITs. Even though there is a basic format to all BITs with standard sections there may be several significant differences in the language contained. For example, one important difference between US BITs and EU BITs is that the US BITs do provide FDI liberalisation. In further research we will also address these differences. In terms of the future EU investment partners, the third countries that have benefited positively from signing BITs with EU member states should be given longer transition periods while member states adjust individual BITs to harmonise with a common EU BIT format.

Table 1. EU27 FDI and BITs

\begin{tabular}{lrrr}
\hline & Number of BITs & Extra-EU27 outward FDI \\
\hline Austria & 65 & & 35,644 \\
Belgium-Luxembourg & 77 & NA \\
Bulgaria & 54 & & 376 \\
Czech Rep & 79 & 446 \\
Denmark & 43 & 48,910 \\
Cyprus & 16 & 4,781 \\
Finland & 62 & 17,864 \\
France & 103 & 354,660 \\
Estonia & 23 & 621
\end{tabular}

\footnotetext{
${ }^{8}$ The results are available upon request.
} 
8 | SElen SARISOy Guerin

\begin{tabular}{lrr} 
Greece & 38 & 9,849 \\
Hungary & 58 & 5,097 \\
Germany & 147 & 334,900 \\
Ireland & 1 & 36,424 \\
Italy & 83 & 80,521 \\
Netherlands & 105 & 203,612 \\
Malta & 22 & 209 \\
Latvia & 43 & 431 \\
Lithuania & 42 & 487 \\
Poland & 62 & 6,354 \\
Portugal & 45 & 16,215 \\
Romania & 84 & 571 \\
Slovakia & 40 & 205 \\
Slovenia & 36 & 4,621 \\
Spain & 61 & 187,820 \\
Sweden & 66 & 78,481 \\
UK & 102 & 603,075 \\
\hline US & 48 & $2,272,056$ \\
Japan & 11 & 489,456 \\
& & \\
Total & 1557 & \\
\hline
\end{tabular}

Source: ICSID, Eurostat.

Table 2. Regional allocation of EU27 BITs

\begin{tabular}{lrrr}
\hline & Africa & Asia & Latin America \\
\hline Austria & 8 & 16 & 7 \\
Belgium-Luxembourg & 17 & 19 & 11 \\
Bulgaria & 4 & 7 & 1 \\
Cyprus & 2 & 3 & \\
Czech Rep & 4 & 11 & 12 \\
Denmark & 8 & 13 & 8 \\
Estonia & & 2 & \\
Finland & 6 & 16 & 12 \\
France & 21 & 24 & 20 \\
Germany & 47 & 26 & 22 \\
Greece & 6 & 8 & 3 \\
Hungary & 4 & 12 & 5 \\
Italy & 18 & 15 & 12 \\
Latvia & 1 & 9 & \\
Lithuania & & 8 & 2 \\
Malta & 3 & & \\
Netherlands & 27 & 19 & 3 \\
Poland & 3 & 14 & 8 \\
Portugal & 12 & 6 & 8 \\
Romania & 10 & 15 &
\end{tabular}




\begin{tabular}{lrrr} 
Slovak Rep & 1 & 8 & 1 \\
Slovenia & 1 & 3 & \\
Spain & 8 & 11 & 19 \\
Sweden & 11 & 16 & 10 \\
UK & 21 & 23 & 19 \\
Total & & & \\
\hline
\end{tabular}

Source: ICSID, World Bank.

Table 3. EU27 BIT partners, FDI stocks, income (million $€$ ) and return

\begin{tabular}{|c|c|c|c|c|}
\hline & $\begin{array}{r}\text { Number of BITs } \\
\text { with the EU }\end{array}$ & EU27 FDI stock & FDI income & Rate of Return \\
\hline Argentina & 18 & 44,103 & 4,139 & $9 \%$ \\
\hline Brazil & 9 & 112,520 & 9,288 & $8 \%$ \\
\hline Chile & 17 & 12,324 & 1,762 & $14 \%$ \\
\hline China & 24 & 47,285 & 3,431 & $7 \%$ \\
\hline Colombia & 2 & 7,178 & 745 & $10 \%$ \\
\hline Egypt & 23 & 20,933 & 1,821 & $9 \%$ \\
\hline India & 19 & 19,362 & 1,825 & $9 \%$ \\
\hline Indonesia & 15 & 13,106 & 1,457 & $11 \%$ \\
\hline Malaysia & 15 & 12,979 & 1,590 & $12 \%$ \\
\hline Mexico & 14 & 49,048 & 3,765 & $8 \%$ \\
\hline Morocco & 17 & 14,133 & 637 & $5 \%$ \\
\hline Russia & 21 & 91,955 & 6,324 & $7 \%$ \\
\hline South Africa & 13 & 46,345 & 4,362 & $9 \%$ \\
\hline Philippines & 13 & 6,260 & 509 & $8 \%$ \\
\hline Thailand & 12 & 10,625 & 395 & $4 \%$ \\
\hline Turkey & 23 & 51,660 & 2,731 & $5 \%$ \\
\hline Czech & 25 & 67,735 & 7,005 & $10 \%$ \\
\hline Bulgaria & 22 & 11,443 & 849 & $7 \%$ \\
\hline Poland & 23 & 86,899 & 6,525 & $8 \%$ \\
\hline Romania & 22 & 31,163 & 2,492 & $8 \%$ \\
\hline Slovenia & 21 & 5,513 & 355 & $6 \%$ \\
\hline Slovakia & 21 & 24,401 & 1,578 & $6 \%$ \\
\hline Korea & 19 & 28,888 & 3,362 & $12 \%$ \\
\hline
\end{tabular}

Source: ICSID, World Bank and Eurostat and author's own calculations.

Table 4. OECD Bilateral Investment Treaties

Dependent variable: $\ln (F D I)_{i j t}$

\begin{tabular}{llll}
\hline & Fixed-effects & Random-effects & OLS \\
\hline Ln GDP $_{i t}$ & $2.74(0.84)^{* * *}$ & $0.05(0.09)$ & $0.06(0.05)$ \\
Ln GDP $_{j t}$ & $2.22(2.52)$ & $-0.07(0.08)$ & $0.02(0.05)$ \\
Ln GDP per capita $_{i t}$ & $-2.11(0.84)^{* * *}$ & $0.52(0.08)^{* * *}$ & $0.57(0.04)^{* * *}$ \\
Ln GDP per capita $_{j t}$ & $-2.51(2.56)$ & $0.52(0.19)^{* * *}$ & $1.23(0.14)^{* * *}$ \\
BIT dummy $^{*}$ & $0.28(0.10)^{* * *}$ & $0.42(0.09)^{* * *}$ & $0.14(0.08)^{*}$
\end{tabular}


10 | SELEN SARISOY GUERIN

\begin{tabular}{llll} 
Ln privatization & $0.05(0.01)^{* * *}$ & $0.04(0.02)^{* *}$ & $0.08(0.02)^{* * *}$ \\
Ln trade & $1.09(0.11)^{* * *}$ & $1.05(0.07)^{* * *}$ & $0.89(0.04)^{* * *}$ \\
Ln distance & & $0.10(0.10)$ & $0.09(0.02)^{* * *}$ \\
Colony & & $0.66(0.63)$ & $0.96(0.19)^{* * *}$ \\
& & & \\
\hline Overall adj-R ${ }^{2}$ & 0.20 & 0.48 & 0.51 \\
Within $\mathrm{R}^{2}$ & 0.17 & 0.16 & \\
$\mathrm{~N}$ & 2079 & 2079 & 2079 \\
F value & 7.19 & & \\
Time dummies & YES & YES & YES \\
\hline
\end{tabular}

Regression with robust standard errors for correction of heteroscedasticity in parentheses.

$* * *$ denotes significance at $1 \%$; ** significant at 5\%; ${ }^{*}$ significant at $10 \%$, - non significant coefficient.

Table 5. EU Bilateral Investment Treaties

Dependent variable: $\ln (F D I)_{i j t}$

\begin{tabular}{|c|c|c|c|}
\hline & Fixed-effects & Random-effects & OLS \\
\hline $\operatorname{Ln~GDP~}_{i t}$ & $-1.72(1.02)^{*}$ & $0.11(0.06)$ & $0.02(0.05)$ \\
\hline $\operatorname{Ln~GDP~}_{j t}$ & $-5.85(3.10)^{*}$ & $0.12(0.08)$ & $0.06(0.05)$ \\
\hline Ln GDP per capita $_{i t}$ & $2.11(1.00)^{* *}$ & $0.41(0.08)^{* * *}$ & $0.57(0.04)^{* * *}$ \\
\hline Ln GDP per capita $_{j t}$ & $6.55(3.24)^{* *}$ & $0.99(0.21)^{* * *}$ & $1.27(0.15)^{* * *}$ \\
\hline EU BIT dummy & $0.20(0.12)^{*}$ & $0.18(0.10)^{*}$ & $0.09(0.08)$ \\
\hline Ln privatization & $0.05(0.02)^{* * *}$ & $0.05(0.02)^{* * *}$ & $0.08(0.02)^{* * *}$ \\
\hline Ln trade & $0.50(0.14)^{* * *}$ & $0.82(0.06)^{* * *}$ & $0.89(0.04)^{* * *}$ \\
\hline Ln distance & & & $0.06(0.05)$ \\
\hline Colony & & & $0.96(0.19)^{* * *}$ \\
\hline Overall adj- $\mathrm{R}^{2}$ & 0.11 & 0.50 & 0.51 \\
\hline Within $\mathrm{R}^{2}$ & 0.20 & 0.20 & \\
\hline $\mathrm{N}$ & 2107 & 2107 & 2079 \\
\hline$F$ value & 7.33 & & \\
\hline Time dummies & YES & YES & YES \\
\hline
\end{tabular}

Regression with robust standard errors for correction of heteroskedasticity in parentheses.

$* * *$ denotes significance at $1 \%$; ** significant at 5\%;* significant at $10 \%$, - non significant coefficient.

Table 6. EU Bilateral Investment Treaties

Dependent variable: $\ln (F D I)_{i j t}$

\begin{tabular}{lll}
\hline & Fixed-effects & Fixed-effects \\
\hline Ln GDP $_{i t}$ & $-1.74(1.03)^{*}$ & $-1.55(1.42)$ \\
Ln GDP $_{j t}$ & $-5.85(3.11)^{*}$ & $-9.08(4.39)^{* *}$ \\
Ln GDP per capita $_{i t}$ & $2.11(1.01)^{* *}$ & $1.84(1.41)$ \\
Ln GDP per capita $_{j t}$ & $6.55(3.25)^{* *}$ & $9.32(4.56)^{* *}$ \\
EU BIT dummy $^{* *}$ & $0.21(0.10)^{*}$ & $0.24(0.14)^{*}$ \\
Ln privatization & $0.05(0.02)^{* * *}$ & $0.07(0.02)^{* * *}$ \\
Ln trade & $0.49(0.13)^{* * *}$ & $0.36(0.17)^{* *}$
\end{tabular}




\begin{tabular}{lll}
$\begin{array}{l}\text { POLITY } \\
\text { RISK }\end{array}$ & $-0.01(0.01)$ & \\
& & $0.04(0.02)^{* *}$ \\
\hline Overall adj-R $^{2}$ & 0.11 & 0.13 \\
Within $\mathrm{R}^{2}$ & 0.20 & 0.21 \\
$\mathrm{~N}$ & 2107 & 1538 \\
F value & 7.24 & 6.22 \\
Time dummies & YES & YES \\
\hline
\end{tabular}

Regression with robust standard errors for correction of heteroscedasticity in parentheses.

$* * *$ denotes significance at $1 \%$; * significant at 5\%; significant at $10 \%$, - non significant coefficient.

Table 7. EU Bilateral Investment Treaties

Dependent variable: $\ln (F D I)_{i j t}$

\begin{tabular}{|c|c|c|}
\hline & Fixed-effects & Fixed-effects \\
\hline Austria BIT & $0.82(0.35)^{* *}$ & $0.64(0.48)$ \\
\hline Denmark BIT & $0.04(0.64)$ & $0.33(0.68)$ \\
\hline Finland BIT & $0.11(0.36)$ & $0.26(0.44)$ \\
\hline France BIT & $1.16(0.31)^{* * *}$ & $1.09(0.38)^{* * *}$ \\
\hline Germany BIT & $-0.44(0.36)$ & $-0.60(0.46)$ \\
\hline Italy BIT & $-0.05(0.25)$ & $0.20(0.30)$ \\
\hline Netherlands BIT & $0.35(0.34)$ & $0.41(0.38)$ \\
\hline Portugal BIT & $-0.87(0.49)^{*}$ & $-0.96(0.74)$ \\
\hline Spain BIT & $0.43(0.32)$ & $0.33(0.34)$ \\
\hline Sweden BIT & $0.45(0.64)$ & \\
\hline UK BIT & $-0.33(0.34)$ & $-0.28(0.38)$ \\
\hline $\operatorname{Ln}_{\text {GDP }}$ it & Yes & Yes \\
\hline $\operatorname{Ln~GDP}_{j t}$ & Yes & Yes \\
\hline Ln GDP per capita $_{i t}$ & Yes & Yes \\
\hline Ln GDP per capita ${ }_{j t}$ & Yes & Yes \\
\hline Ln privatization & Yes & Yes \\
\hline Ln trade & Yes & Yes \\
\hline RISK & & $0.05(0.02)^{*}$ \\
\hline Overall adj- $\mathrm{R}^{2}$ & 0.11 & 0.13 \\
\hline Within $\mathrm{R}^{2}$ & 0.22 & 0.22 \\
\hline $\mathrm{N}$ & 2107 & 1538 \\
\hline F value & 6.24 & 5.35 \\
\hline Time dummies & YES & YES \\
\hline
\end{tabular}

Regression with robust standard errors for correction of heteroscedasticity in parentheses.

$* * *$ denotes significance at $1 \%$; ** significant at 5\%;* significant at $10 \%$, - non significant coefficient. 
Table 8. EU Bilateral Investment Treaties

Dependent variable: $\ln (\mathrm{FDI})_{i j t}$

\begin{tabular}{|c|c|c|}
\hline & Fixed-effects & Fixed-effects \\
\hline Argentina & $0.39(0.41)$ & NS \\
\hline Chile & $-0.41(0.38)$ & NS \\
\hline China & $-0.58(0.71)$ & \\
\hline Bulgaria & $-0.32(0.40)$ & $-0.90(0.53)^{*}$ \\
\hline Czech R & $-0.42(0.71)$ & NS \\
\hline Egypt & $0.37(0.72)$ & NS \\
\hline Hungary & $-2.71(1.35)^{* *}$ & $-2.65(1.33)^{* *}$ \\
\hline Indonesia & $-0.55(0.27)$ & NS \\
\hline India & $0.18(0.27)$ & NS \\
\hline Mexico & $0.55(0.56)$ & NS \\
\hline Morocco & $-0.41(0.57)$ & NS \\
\hline Philippines & $0.90(0.47)^{* *}$ & $1.00(0.54)^{*}$ \\
\hline Poland & $-0.20(0.53)$ & NS \\
\hline Romania & $1.09(0.33)^{* * *}$ & $1.01(0.38)^{* * *}$ \\
\hline Russia & $-0.66(0.89)$ & \\
\hline South Africa & $0.62(0.36)^{*}$ & NS \\
\hline Slovenia & $1.16(0.64)^{*}$ & \\
\hline Slovak R & $-0.05(0.84)$ & NS \\
\hline Thailand & $0.40(0.75)$ & NS \\
\hline Turkey & $0.02(0.53)$ & NS \\
\hline $\operatorname{Ln~GDP~}_{i t}$ & Yes & Yes \\
\hline $\operatorname{Ln~GDP~}_{j t}$ & Yes & Yes \\
\hline Ln GDP per capita $_{i t}$ & Yes & Yes \\
\hline Ln GDP per capita ${ }_{j t}$ & Yes & Yes \\
\hline Ln privatization & Yes & Yes \\
\hline Ln trade & Yes & Yes \\
\hline RISK & & $0.04(0.02)^{*}$ \\
\hline Overall adj-R ${ }^{2}$ & 0.12 & 0.13 \\
\hline Within $\mathrm{R}^{2}$ & 0.22 & 0.23 \\
\hline $\mathrm{N}$ & 2107 & 1538 \\
\hline F value & 6.71 & 5.80 \\
\hline Time dummies & YES & YES \\
\hline
\end{tabular}

Regression with robust standard errors for correction of heteroscedasticity in parentheses.

$* * *$ denotes significance at $1 \%$; ** significant at 5\%; significant at $10 \%$, - non significant coefficient.

NS Not significant. 


\section{References}

Aisbett, E. (2008), "Bilateral Investment Treaties and Foreign Direct Investment: Correlation versus Causation", mimeo, Australian National University.

Baier, S.L. and J. Bergstrand (2007), "Do free trade agreements actually increase members' international trade?", Journal of International Economics, Vol. 71, pp. 72-95.

Baltagi, B. (2001), Econometric Analysis of Panel Data, West Sussex: John Wiley and Sons Ltd.

Busse, M., J. Koniger and P. Nunnenkamp (2008), FDI promotion through bilateral investment treaties: more than a bit?, Kiel Working Paper No. 1403, Kiel Institute for the World Economy, Kiel.

Egger, P. and M. Pfaffermayr (2003), "The impact of bilateral investment treaties on foreign direct investment", Journal of Comparative Economics, Vol. 32, No. 4, pp. 788-804.

Eschenbach, F., J. Francois and S. Nitzsche (2004), "Economic Growth In 130 Countries: A New Dataset on Development and Finance", mimeo (http://www.i4ide.org/francois/data.htm).

European Commission (2010), Roadmap: Proposal for a Regulation of the European Parliament and the Council establishing transitional arrangements for international investment agreements between Member States and third countries (http://ec.europa.eu/governance/ impact/planned_ia/docs/86 trade international investment_agreements_en.pdf).

Hallward-Driemeier, M. (2003), Do bilateral investment treaties attract FDI? Only a bit and they could bite, World Bank Policy Research Paper WPS 3121, World Bank, Washington, D.C.

Helpman, E., M. Melitz and Y. Rubinstein (2007), Estimating Trade Flows: Trading partners and trading volumes, NBER Working Paper No. 12927, National Bureau of Economic Research, Cambridge, MA.

Neumayer, E. and L. Spess (2005), "Do bilateral investment treaties increase foreign direct investment to developing countries?", World Development, Vol. 33, No. 10, pp. 15671585 .

Persson, T. (2005), "Forms of democracy, policy and economic development", mimeo, Institute for International Economic Studies, Stockholm University.

Razin, A., Y. Rubinstein and E. Sadka (2003), Which countries export FDI, and how much?, NBER Working paper No. 10145, National Bureau of Economic Research, Cambridge, MA.

Salacuse, J. and N. Sullivan (2004), "Do BITs really work? an evaluation of bilateral investment treaties and their grand bargain", Harvard International Law Journal, Vol. 46, No. 1.

Tobin, J. and S. Rose-Ackerman (2004), Foreign direct investment and the business environment in developing countries: The impact of bilateral investment treaties, Economics and Public Policy Research Paper No. 293, Yale Law School Center for Law, New Haven. 